\author{
현대 패션에 나타난 큐비즘스타일패션 연구: \\ 2010 S/S - 2013 S/S 파리컬렉션을 중심으로 \\ 최예리 · 최정욱 \\ 경희대학교 아트퓨전디자인대학원 패션아트학과, 경희대학교 의류학과 ${ }^{+}$
}

\title{
A Study on Cubism Fashion Style Appearing in Modern Fashion: \\ Focused on the 2010 S/S-2013 S/S Paris Collection
}

Choi Yeree $\cdot$ Choi jeongwook ${ }^{+}$

Dept. of Fashion Art Graduate School of Art Fusion Design, Kyung Hee University

Dept. ofClothing \& Textile Design, Kyung Hee University ${ }^{+}$

\begin{abstract}
This study analyzed the group of experts who were related to cubism, selected among th e works of 2010 2013 Paris Collection based on F.G.R.(Focus Group Research). According to the results of this study, there were appeared first, 'a one-piece dress' second, 'H silh ouette' third, 'cotton', in case of item distribution and frequency. The analysis was done b $y$ using the manner of expression, cubical expression, exaggeration, distortion, dismantleme nt, geometrical division of face, mix-match look, wraparound-repetition, asymmetric structur e, etc. Based on the outcomes of the analysis on figurative design elements, this study ad justed three manners appearing on cubism fashion style. First, it was 'avant garde manner' of constitution or 'dismantlement' which was compiled into multi-view representations of ov erlaps and viewpoints by repetitive use of color tone-trimming.detail. Second, it was 'geom agnetic block placement' which expresses cubism with geometric partitioning of surface an d separation of panel by cutting disintegration. Finally, it was "distortion and simplification of silhouette' which is a distortion created by constitution-line pressed thin with silhouette. It maximizes the beauty of human body outline, which was distorted by three-dimensionalmanipulation, and simplified by ellipsis for another shape for the extension or expansion of detail trimming.
\end{abstract}

Corresponding author: Choi Jeongwook, Tel. +82-10-8958-0701, Fax. +82-31-273-0127

E-mail: jwchoi@khu.ac.kr

This research is a part of master's thesis. 
최예리 · 최정욱 / 현대 패션에 나타난 큐비즘스타일패션 연구

Key words : cubism(큐비즘), distortion of silhouette(실루엣의 왜곡), geomagnetic(지오메틱), transposition(전위성)

\section{I. 서 론}

최근 패션계에서는 획일적이고 평범한 스타일은 지양되고 실험적인 디자인이 많이 시도되고 있으며 소비자들의 요구 또한 기능성과 같은 보편적이고 실 용적인 목적보다는 장식성·독창성·심미성 등에 더 많은 관심을 갖게 되었다. 20 세기에 등장한 예술 운 동 중 하나인 큐비즘은 지속적으로 패션 디자이너들 에 의해 지속적인 영감의 원천으로 해석되어 왔다 (Sung, 2010). 20세기 미술 사조의 변혁이었던 큐 비즘은 입체적 표현의 새로운 시도였으며, 기존의 원근법을 부정하는 동시표현의 방법을 시도하였고 2 차원의 평면 위에 3 차원적인 공간 감각을 추구하며 예술영역의 확대에 큰 영향을 주었다. 예술사에서 15 세기 원근법을 제 1 의 혁명이라 한다면 그 이후 제2의 혁명은 20 세기 초 큐비즘이라 할 정도로 현 대의 추상예술을 잉태시킨 큐비즘이 차지하는 위치 는 지대하다(Yoon, 2006). 또한 현대미술의 저류가 된 큐비즘이 근대 복식을 벗어나 모더니즘으로 향하 는 20 세기 현대 패션에 미친 영향은 지대한 것으로 표현영역에서 상호간의 일치성을 나타내는 부분이 있다고 할 수 있다(D. Lee, 2003).

이에 본 연구에서는 큐비즘이 패션디자인에 어떠 한 방식으로 영향을 끼쳤는지 알아보기 위해 큐비즘 패션 스타일의 조형적 디자인 요소를 분석하고 이를 통해 큐비즘스타일패션의 특성을 정리해보고자 하였 다.

큐비즘과 패션과의 연관성에 관한 연구를 살펴보 면, 대부분이 문헌연구에 기초한 미학적 연구이거나, 주관적 해석을 통한 작품 디자인을 제안한 연구가 대부분으로 큐비즘과 패션에 대한 객관적 연구는 미 비한 실정이다. 이에 본 연구는 전문적이고 객관적 인 방법을 통해 현대 패션 디자인에서 나타난 큐비 즘적 디자인 요소를 분석하고, 큐비즘과 현대 패션 과의 연관성을 정리하고자 한다.

본 연구는 객관적이고 논리적인 절차를 통해 큐비
즘적 패션 스타일을 규명하고, 이를 하나의 패션 스 타일로 확립하는 데 목적이 있다. 이를 통해 20세기 미술의 신호탄이 된 큐비즘이 패션 디자인 영역에서 큐비즘스타일패션으로 발전해 갈 가능성을 제안하고 현대 패션에 나아갈 방향을 제시하는데 의의가 있 다.

\section{II. 이론적 배경}

\section{1. 큐비즘의 개념 및 발생배경}

큐비즘은 20세기 초 야수파 운동과 전후해서 프랑 스를 중심으로 1907년부터 1914년 사이에 일어났던 파리의 아방가르드 미술운동으로서 실험적인 운동이 었다. 매년 가을에 개최되는 프랑스 미술 단체 전시 회인 살롱도톤(Salon d'Automne)에 1908년 출품된 브라크의 「레스타크의 집들」이란 연작에 대해 심 사위원장이었던 마티스(Henri Matisse, 1869-1954) 가 '조그만 입체(큐브)의 덩어리'라고 말한 데서 유 래되었다(Edward, 1985).

큐비즘이 발생하기 전인 제 1 차 세계 대전 직전의 10 년 간 파리는 사치와 향락의 본거지로서의 역할도 하였지만 경제 붐을 주도하던 자본주의의 역학에 따 라 사회 불평등이 더욱 심화되었고, 이에 따라 사회 주의, 노동자 계층과 페미니즘 운동의 거센 저항에 부딪치게 되었다. 이후 1914년의 세계대전이 발생하 였으며 이 복잡하고 역동적인 사회 안에서 다양한 예술적 아방가르드 공동체가 형성되었다.

큐비즘 회화는 이전 회화 기법과 달리 불안정한 구조와 공간 배열 및 최소한의 색채사용을 하였다. 뿐만 아니라, 작품 속 인물이 투과되거나 뒤섞여 정 물이나 풍경을 구분할 수 없도록 함으로써 유머러스 한 표현을 보여주었다. 게다가 르네상스 미술에 대 한 그들의 도전은, 그들의 작품이 근본적으로 같아 보이지는 않더라도 전통적인 회화와 조각에 대한 지 
식을 바탕으로 한 것에 의해 적당히 완화되었다. 즉, 입체주의는 미술 작품이 또 다른 공간으로의 창문 역할을 한다는 평범한 개념을 거부하고, 세상을 보 고 앎으로써 미술이 진정으로 '있는 그대로의' 세상 을 다룰 수 있다고 주장하였다(Neil, 2003).

\section{2. 패션에 있어서의 큐비즘}

현대패션과 미술사조는 서로 장르는 다르지만, 창 작세계 안에서 추구하는 바가 일맥상통한다. 현대미 술의 저류가 된 큐비즘이 근대복식을 벗어나 모더니 즘으로 향하던 20 세기 현대패션에 미친 영향은 지대 하였으며 현대패션의 표현영역에서 상호 간의 일치 성을 나타낸다고 할 수 있다(Yu \& Kim, 1993).

20 세기 초반 패션은 기능주의와 더불어 직선형 실 루엣이 시도되어 인체의 자연미가 추구되며 복식에 많은 영향력을 발휘하였으며, 모드는 이러한 기능주 의의 영향으로 합리적인 의상이 전개되는 모던 스타 일이 정착되기 시작하였다. 큐비즘의 영향을 받은 패션 디자인은 합리성과 구조적인 기능성을 강조한 간결미를 추구하였으며 명쾌한 색채와 기하학적인 문양 그리고 단순한 실루엣의 형태를 추구하였다. 아르누보의 과잉장식인 S-curve 스타일에서 벗어나 완전히 원통형의 단순한 실루엣을 발표하는 등 이러 한 요소들은 큐비즘의 기하학적 단순미와 밀접한 관 계가 있다(Chae, 2002). 이브 생 로랑은 1988년 $\mathrm{S} / \mathrm{S}$ 컬렉션의 테마로 큐비즘을 도입하여 화제를 불
러일으켰다. 그는 피카소와 더불어 큐비즘을 창시한 프랑스의 거장 브라크의 그림을 그대로 정교하게 수 놓은 입체화된 패션을 선보였다. 큐비즘이 패션에 미친 영향은 단순성, 실용성, 기능성 등 큐비즘의 표현기법 뿐만 아니라, 큐비즘이 사물을 분해시키고 재구성하여 사울의 본질을 찾고자 했던 것처럼 패션 도 좀 더 내면적인 면을 추구하께끔 영향을 끼쳤고 큐비즘의 조형적 특징은 현대 패션의 새로운 방향을 제공하였다고 볼 수 있다(E. Lee, 2002).

Table 1의 큐비즘에 관련된 선행 연구를 살펴보 면, Sung(2011)은 분석적 큐비즘 단계의 기하학적 형태미를 연구하고, 이를 응용한 패션디자인 사례를 분석하여 큐비즘 시대의 풍부한 기하학적 조형성을 의상에 응용한 디자인을 제안하였다. Song(2009)은 큐비즘 패션 디자인을 사실성, 동시성, 도형성, 해체 와 재구성, 중첩성으로 분석하였으며 큐비즘이 활용 된 큐비즘 패션의 조형성을 파악한 후, 그 안에 내 재된 조형미를 도출하여 작품을 제작-제안하였다. D. Lee(2003)는 큐비즘 회화의 조형성을 분석하고 현대 패션 디자인에 표현된 큐비즘의 조형적 특성들 을 분류·분석하였고 이를 바탕으로 새로운 디자인 모티브를 제시하였다. Kang(1992)은 큐비즘의 흐름 을 살펴보고 현대 회화와 패션과의 관계를 분석하였 으며, 그중에서도 피카소의 큐비즘 작품을 분석하여 복식디자인에 응용하여 표현하였다. 위의 선행 연구 에서 살펴본 큐비즘 패션의 조형성을 자세히 살펴보 면 다음과 같다.

Table 1. Cubism Fashion's Formativeness Based on Preceding Studies

\begin{tabular}{c|c|c|c|c|c}
\hline (year) & $\begin{array}{c}\text { Shapes } \\
\text { (physical } \\
\text { beauty) }\end{array}$ & $\begin{array}{c}\text { Dismantlement } \\
\& \\
\text { reconstitution }\end{array}$ & Overlap & $\begin{array}{c}\text { Multi-view } \\
\text { (simultaneity) }\end{array}$ & Reality \\
\hline $\begin{array}{c}\text { Sung, P. } \\
\text { (2011) }\end{array}$ & 0 & & 0 & 0 & 0 \\
\hline $\begin{array}{c}\text { Song, A. } \\
\text { (2009) }\end{array}$ & 0 & 0 & & & \\
\hline $\begin{array}{c}\text { Lee, D. } \\
\text { (2003) }\end{array}$ & 0 & & & & \\
\hline $\begin{array}{c}\text { Kang, K. } \\
\text { (1992) }\end{array}$ & 0 & 0 & & & \\
\hline \hline
\end{tabular}


최예리 · 최정욱 / 현대 패션에 나타난 큐비즘스타일패션 연구

\section{1) 도형성}

큐비즘 회화에서 보이는 선의 기하학적 조형미와 다채로운 화면의 분할은 편안하고 자연스럽게 인체 에 일착되면서 단순한 실루엣을 원하는 현대의 트렌 드에 부합하며 패션에 변화를 줄 수 있는 디자인 요 소로 현대 패션 디자인에 다양한 모습으로 적용되고 있다(Ju, 1990).

서로 다른 크기의 도형들이 점진적인 강조로 시선 을 유도하여 착시현상을 일으킴으로써 인체의 특정 부위를 부각하거나, 톤 온 톤(tone on tone) 배색을 통한 평면 공간의 입체감 부여, 인체에 둘러지면서 인체를 따라 생기는 표면의 나선이나 율동으로 인해 유연한 실루엣으로 바뀌어 이지적인 이미지로 만들 기도 한다. 또한, 서로 크기가 다른 개체를 점증적 으로 반복, 배열함으로써 시선을 확장시키고 비대칭 과 사선의 움직임을 통한 기하학 도형의 대비와 움 직임에 따른 역동성이 도형성 안에 포함될 수 있다.

\section{2) 해체와 재구성}

큐비즘 패션의 해체와 재구성은 형태요소 중 가장 기본적인 선, 면, 아이템의 형태에 대한 조화를 파 괴하여 해체하고 불규칙하게 재구성하여 새롭고 다 양한 형태로 나타난다. 즉, 큐비즘 회화에서 선이 대상을 분해하여 새롭게 구성하는 매개로 사용되는 것처럼 패션에서 선은 의복구성의 패턴을 해체해 재 구성하는 용도로 절개선, 혹은 여러 가지 재료를 사 용한 장식 선으로 표현되어 단조로운 실루엣에 변화 를 주고 시선을 끄는 효과를 낸다. 또한, 다채로운 화면의 분할은 패션에 변화를 줄 수 있는 디자인 요 소로써 현대 패션 디자인에 다양한 모습으로 적용되 고 있다. 선에 의한 해체와 재구성을 살펴보면 장식 선을 활용하여 다양한 사선에 의해 분할된 면을 사 선과 바탕의 색대비로 인하여 선을 강조시키거나, 의복구성 시 서로 다른 색상의 패널들을 재구성하여 명도 대비에 의한 시각적 즐거움을 준다. 이러한 해 체와 왜곡은 단순히 디자인 요소와 패턴에만 한정되 는 것이 아니라 다양한 소재의 믹스매치를 통해서도 정형화되지 않게 변화를 주고 재구성하여 생동감과
자유로움을 느끼게 한다.

3) 중첩성

큐비즘 패션에서의 중첩성은 기하학형 도형을 크 기의 변화를 주어 도형들을 연속적으로 반복, 중첩 하거나 동일한 소재에 상이한 컬러의 아이템을 중첩 시켜 다른 아이템을 입고 있는 것처럼 과장된 실루 엣을 만들 수 있다. 또한 동일한 컬러, 소재의 러플 을 중첩할 수 있으며 여러 아이템을 여러 층으로 겹 겹이 쌓아올려 부풀려서 실루엣을 만들 수도 있다. 이처럼 현대 패션에 나타난 큐비즘의 두드러진 특징 은 의상의 전체적인 외형에 있어 형태의 변형과 왜 곡에 있으며, 이것은 구성에 있어 기존의 규칙을 버 리고 더욱 기초적인 조형방법으로 구성해나가 기하 학적인 형태에 의해 실현되고 있다(E. Lee, 2002).

4) 동시성

큐비즘 회화에서의 동시성은 현대패션에서 인체에 대한 고정적 관념, 즉 인간이 만들어 놓은 아름다운 신체에 대한 전통의 미학적 가치를 거부하며 20세기 전반까지 신체의 보호와 미적 기능을 목적으로 하였 던 전통의 관습적 편견들을 해체하고자 하였다 (Park, 2004).

큐비즘 패션에 나타난 동시성은 시점의 각도에 따라 아이템이나 디자인 요소가 갖고 있는 다양한 기능을 변형시키는 방식으로, 앞여밈이 항상 정면에 있어야 하는 정형화 된 셔츠와 재킷의 착장 방식을 부정하여 앞여밈을 어깨 쪽으로 구성하여 시선을 집 중시켜 아이템 형태의 상상을 할 수 있도록 시각적 재미를 나타내기도 하고, 재킷 위에 원피스를 겹쳐 입은 듯 한 느낌을 주면서 왜곡되어 나타나며 원피 스는 재킷의 패널에 의해 마치 원피스 위에 재킷을 입은 듯 한 시각적 착각을 주며 한 벌에 두 가지의 아이템이 동시에 관찰되게 표현하기도 하였다.

5) 사실성

큐비즘 패션에서의 사실성은 일상생활에서의 재료 
로서 성질과 본질을 지닌 전혀 왜곡된 재료가 아님 에도 불구하고 그 재료를 의상에 도입하여 모호하게 왜곡되어 전위적인 조형미로 나타났다(Song, 2007). 다른 용도로 쓰이는 의외의 소재를 왜곡하여 사용하 기도 하며, 특이한 소재를 새로운 기법으로 패션에 전위적으로 표현하기도 한다. 이러한 새롭고 실험적 인 제 3 의 소재 도입으로 인해 의외성과 부조화를 유 발하는 동시에 유희적인 일종의 그로테스크를 나타 내었다(Chae, 2002).

재료로는 인공물, 동물, 자연물 등의 다양한 종류 가 사용되고 있는데 인공물의 금속 재료를 이용한 디자인 사례를 보면 금속으로 바디스(badies)를 성 형하고 씨퀸으로 장식한 팔, 다리는 빛의 명암효과 로 인해 관능적인 이미지를 주며 관찰자의 시선을 바디스(badies)쪽으로 집중시켜 점차적으로 씨퀸으 로 장식된 팔, 다리 쪽으로 시선을 이동시켜 시각적 확장을 유도하기도 한다.

\section{III. 연구방법 및 절차}

본 연구는 큐비즘스타일패션 선정을 위한 1 차 F.G.R. 연구와 큐비즘스타일패션의 조형적 디자인 요소 분석을 위한 2차 F.G.R. 연구로 나누어 진행되 었다.

\section{1. 큐비즘스타일패션 선정을 위한 연구 (1차 F.G.R.)}

본 연구는 2012년 12월 28일부터 2013년 1월 9 일까지 기간 중 10 일 동안 실시되었으며, 연구범위 는 2010년 S/S부터 2013년 S/S까지 파리 컬렉션에 발표된 모든 작품을 대상으로 하였다. 자료의 출처 는 패션 정보 사이트 firstviewkorea.com에서 제공 되는 컬렉션 사진을 중심으로 진행되었으며, 분석 자료는 3년여 동안 7회 파리 컬렉션에 나타난 총 199 명의 디자이너의 26,883 점의 작품 전체를 대상 으로 하였다. 2010년 S/S부터 2013년 S/S까지의 파리 컬렉션을 선정한 이유는 연구시점에서 최근 컬 렉션에 나타난 큐비즘 적 동향을 알아보기 위함이
고, 세계 4대 컬렉션인 파리컬렉션, 밀라노 컬렉션, 뉴욕 컬렉션, 런던 컬렉션 중에서 파리 컬렉션을 선 택한 이유는 4대 컬렉션 중 가장 큐비즘 적 성향이 두드러지게 나타나 연구에 적합하다고 판단하여 결 정하게 되었다.

컬렉션 작품 중 큐비즘과 관련성이 있는 패션스타 일을 큐비즘스타일패션으로 선정하기 위해 F.G.R.을 실시하였다. 이는 보다 전문적이고 객관적인 판단을 통해 결과에 대한 신뢰도를 높이기 위함이다. F.G.R.에 참여한 전문가는 의류디자인학을 전공한 석사학위 이상인 자로, 연구 및 실무경력 10년 이상 되는 전문가 5 명으로 구성하였다.

본 연구는 컬렉션에 나타난 패션스타일 중 큐비즘 에 영향을 받은 스타일을 추출해내기 위해 전문가 집단을 대상으로 26,883 개의 컬렉션 사진을 보여주 고 각각의 스타일에 대해 큐비즘과의 관련성 정도를 5점 리커드 척도로 판단하게 하였다. F.G.R.의 진행 은 정해진 시간에 5 명의 구성원이 한자리에 모여 모 니터 상에 제시되는 패션 스타일에 대해 리커드 척 도에 따른 점수를 무기명으로 각각 평가하도록 하였 다. 집중도를 높이기 위해 동일 장소에 모여 진행하 되, 서로 간 상의과정 없이 비밀평가 방식으로 유도 진행 하였다.

\section{2. 큐비즘스타일패션의 조형적 디자인 요소 분석을 위한 연구 (2차 F.G.R.)}

본 연구는 2013년 2월 5일부터 2월 7일까지 3일 간에 걸쳐 실시되었으며, 연구범위는 선행된 1 차 F.G.R.을 통해 큐비즘스타일패션으로 분석·선정된 19 명의 디자이너, 90 점의 큐비즘스타일패션을 대상 으로 하였다.

1차 F.G.R.에서 선정된 90점의 큐비즘스타일패션 에 대한 전·후·측면 및 디테일 사진을 연구대상으로 하였다. 이들 90 개 스타일의 조형적 디자인 요소를 분석하고자 아이템, 실루엣, 색상, 배색, 소재, 디테 일, 트리밍 등 7 개 요소를 분석 변수로 사용하였다. 7 개 요소 각각의 세부항목은 요소별로 수를 달리하 여 총 85 개의 항목을 통해 해당 사항 여부를 분석하 였다. 색상의 경우에는 PANTONE TEXTILE 컬러칩 
을 사용하여 정확한 색상분석을 시도하였다.

보다 전문적이고 객관적인 평가를 통해 결과에 대 한 신뢰도를 높이기 위해 1차 연구와 마찬가지로 2 차 연구에서도 F.G.R.을 실시하였다. F.G.R.의 구성 은 의류디자인학을 전공한 석사학위 이상인 자로, 연구 및 실무경력 6 년 이상의 전문가 10 명을 선정 하였다.

\section{IV. 연구 결과 및 고찰}

\section{1. 큐비즘스타일 선정을 위한 연구 결과}

F.G.R.의 구성원인 패션 전문가 5인에게 2010년 $\mathrm{S} / \mathrm{S}$ 부터 2013년 S/S까지 파리컬렉션에 발표된 총 26,883 점 전체 작품을 대상으로 각 작품에서 보이 는 큐비즘 관련 정도를 리커드 척도로 표시하도록 하여 분석한 결과는 다음과 같다.

먼저 연구범위의 시즌별 빈도수를 살펴보면, $\mathrm{S} / \mathrm{S}$ (15132, 56.29\%), F/W(11751, 43.71\%)이다. S/S 컬렉션의 작품 수가 $\mathrm{F} / \mathrm{W}$ 컬렉션의 작품 수 보다 많 게 조사되었으며 각 연도별 빈도수를 분석해본 결과 2011년(7919, 29.46\%), 2010년(7468, 27.78\%), 2 012년(7414, 27.58\%), 2013년(4082, 15.18\%) 순으 로 나타났다. 2010년에서 2013년까지 파리 컬렉션 에 참여한 디자이너에 대해 조사한 결과, 총 199명 인 것으로 나타났으며 이들 디자이너 중 조사범위 동안 매회 컬렉션에 빠짐없이 참여한 디자이너는 53 명인 것으로 분석되었다.

F.G.R.의 구성원인 전문가 5 명에게 26,883 점의 파리 컬렉션 작품 각각에 대한 큐비즘과의 관련성을 5점 리커드 척도를 통해 평가하도록 하였으며 이때 검사자 간 평가결과의 신뢰도를 알아보기 위하여 상 관분석을 실시하였다. 분석결과 평가자 1 부터 평가 자 5까지 모두 각각 유의수준 0.01 하에서 상관관계 가 존재함을 알 수 있었으며 이를 통해 평가자들 간 의 응답 경향이 비슷함을 알 수 있고, 평가자들 간 의 응답을 신뢰할 수 있다고 판단할 수 있었다.

큐비즘스타일의 시즌 분포를 살펴보면 $\mathrm{S} / \mathrm{S}(268$, $50.09 \%)$ 와 $\mathrm{F} / \mathrm{W}(267,49.91 \%)$ 가 거의 같은 정도로
나타났는데, 이는 파리 컬렉션에서 시즌에 상관없이 큐비즘스타일이 선보여진 것으로 분석되었다. 다음 으로 큐비즘스타일의 연도별 출현 빈도를 분석한 결 과 전반적으로 매해 출현 빈도가 유사하였으나 201 1년도의 경우 빈도가 높게 나타났다. 즉, 2010년도 (138, 25.79\%)에 비해 2011년도(231, 43.18\%)에 눈에 띄게 큐비즘스타일이 많이 선보여진 것으로 나 타났다. 이는 2010년도에 전 세계적으로 불어 닥친 경제적 불황이 끼친 영향이라 분석할 수 있다. 즉, 불황일수록 디자이너들의 발명 및 창작에 대한 요구 가 커진다는 분석에 근거하듯, 2010년 불황기에 새 로운 것에 대한 열망이 커진 디자이너들이 2011년 부터 조심스럽게 예견되는 경기 회복의 기미를 발판 으로 긍정적이고 경쾌한 분위기를 디자인한 것으로 해석할 수 있다. 즉, 2010년 F/W 시즌에는 안정과 현실의 기반 위에 새로운 변화와 재미를 추구하는 시즌이었으며 생각지 못한 방식과 결합으로 세련된 창조물을 만들어내기 시작한 것으로 볼 수 있다(Inte rnet Site, firstviewkorea). 그 결과 큐비즘스타일패 션과 같은 새로운 스타일이 많이 선보여지게 된 것 으로 사료된다.

큐비즘스타일을 제안한 디자이너를 조사한 결과 전체 디자이너 199명 중 49명으로 전체의 $24.62 \%$ 에 해당하였다. 이들 디자이너 중 큐비즘스타일의 디자인을 매년 출현 빈도가 10 이상으로 제작한 디 자이너로는, 꼼 데 가르송 $(110,20.56 \%)$, 알렉산더 맥퀸(44, 8.22\%), 매니쉬 아로라(36, 6.73\%), 빅터 앤 롤프(28,5.23\%), 메종 마틴 마르지엘라와 파코 라반(26, 4.86\%), 아마야 아르주아가(24, 4.49\%), 티에리 위글러(22, 4.11\%), 페드로 로렌코(19, 3.5 $5 \%)$, 아르주 캐프롤과 릭 오웬스 $(17,3.18 \%)$, 파티 마 로페즈, 가레스 푸, 이세이 미야케(14, 2.62\%), 이상봉(12, 2.24\%), 발렌시아가(11, 2.06\%) 순으로 나타났다. 이들 중 아시아계 디자이너로 꼼 데 가르 송의 레이 가와쿠보와 이세이 미야케가 있으며, 특 히 한국계 디자이너로는 이상봉, 문영희 등이 큐비 즘스타일패션 디자이너로 분류되었음을 알 수 있다.

\section{2. 큐비즘스타일패션의 조형적 디자인 요소 분석을 위한 연구 결과 (2차 F.G.R.)}


1차 F.G.R.을 통해 큐비즘과의 관련성에서 4점 이상의 점수를 받은 535 개의 큐비즘스타일 작품 중 다시 4.75점 이상의 점수를 받은 90 개의 작품만을 선별하여 이들 작품의 전·후·측면 및 디테일 사진을 면밀히 분석하였다.

이때 사용된 변수 7 개의 조형적 디자인 요소를 기 준으로 85 개 세부항목에 따라 분석하였다. 보다 전 문적이고 객관적인 판단을 통해 결과에 대한 신뢰도 를 높이기 위해 1차 연구와 마찬가지로 2차 연구에 서도 F.G.R.을 실시하였다. F.G.R.의 구성은 의류디 자인학을 전공한 석사학위 이상인 자로, 연구 및 실 무경력 6 년 이상의 전문가 10 명을 선정하여 진행하 였다.

앞서 설명한 바, 조형적 디자인 요소 분석을 위해 1 차 F.G.R.의 평가 결과에서 4.75점 이상의 점수를 받은 90 개의 작품을 큐비즘스타일패션으로 정하고 이들의 조형적 디자인 요소를 분석하였다. 평가자 평균점수가 5점 이상인 경우는 32(3.07\%), 4.75점 이상인 경우는 $90(8.64 \%), 4.50$ 점 이상인 경우는 1 $60(15.36 \%), 4.25$ 점 이상인 경우는 225(21.59\%), 4점 이상인 경우는 $535(51.34 \%)$ 로 나타났다. 이에 평가 값 4.75 이상인 작품 90 점을 본 논문의 2 차 연 구 대상으로 선정하였다.

큐비즘스타일패션에 나타난 아이템의 종류를 살펴 본 결과, 원피스(482, 32.70\%), 재킷(199, 13.50\%) 순으로 높게 나타났으며 롱 슬랙스, 블라우스/셔츠, 드레스, 코트 등 20여개의 다양한 아이템이 출현한 것으로 조사되었다. 원피스의 출현 빈도가 가장 많 은 이유는 실루엣을 통한 형태 표현이나 입체적 디 테일을 통한 큐비즘적 표현이 용이한 아이템이기 때 문으로 생각된다.

다음으로 큐비즘스타일패션의 실루엣 분포를 살펴 본 결과, $\mathrm{H}$ 실루엣(392, 43.6\%), $\mathrm{O}$ 실루엣(192, 2 1.3\%), A 실루엣(161, 17.9\%), Y or T 실루엣(100, $11.1 \%$ ) 순이었다. 이 중에서 $\mathrm{H}$ 실루엣이나 $\mathrm{O}$ 실루 엣이 높은 빈도로 나타난 것은 심플하고 기하학적 형태로 표현되는 큐비즘 성향과 일치한다고 사료된 다. 뿐만 아니라, $X$ 실루엣 $(55,6.1 \%)$ 의 빈도가 가 장 낮게 나타난 이유는 $X$ 실루엣이 여성적이고 곡선 적인 느낌이 강한 실루엣이므로 큐비즘의 심플하고
기하학적인 스타일과 대치되기 때문으로 분석되었 다.

큐비즘스타일패션의 각 스타일마다 사용된 색상을 모두(중복응답) 분석한 결과, 총 49 가지의 색상이 사용되었음을 알 수 있었다. 주로 사용된 색상은 레 드 계열, 옐로우 계열, 블루 계열 색상 정도로 국한 되었으며 저채도나 무채색의 빈도가 높은 것으로 분 석되었다.

큐비즘스타일패션에 나타난 배색 방법을 분석한 결과, 솔리드(solid)(498, 55.3)\%가 과반 수 이상으 로 가장 많이 응답하였고, 톤 인 톤(tone in tone)(1 $50,16.7 \%)$, 톤 온 톤(tone on tone)(130, 14.4\%), 세퍼레이트(separate)(122, 13.6\%) 순으로 나타났 다. 솔리드가 많이 사용된 것은 심플하고 입체적인 형태 표현을 주로 하는 큐비즘적 성향을 표현하기에 솔리드가 적합한 배색 방법이기 때문인 것으로 사료 되었다. 즉, 직선적, 곡선적 혹은 입체적으로 실루엣 이나 디테일을 강조하는 경우, 색상에 의한 표현을 절제해야 하는 디자인 원리를 활용하기 때문인 것으 로 생각되었다.

큐비즘스타일패션에 사용된 소재의 분포를 살펴보 면, 면(279, 19.73\%), 새틴(158, 11.17\%), 메탈릭(1 $32,9.34 \%)$, 가죽(130, 9.19\%), 실크(127, 8.98\%), 쉬폰(77, 5.45\%), 펠트(69, 4.88\%), 모(66, 4.67\%), 벨벳(58, 4.10\%), 저지(54, 3.82\%), 니트(42, 2.9 $7 \%)$, 에나멜(40, 2.83\%), $\mathrm{T} / \mathrm{C}(38,2.69 \%)$, 패딩(3 $5,2.48 \%)$, 마(27, 1.91\%), 비닐(26, 1.84\%), 퍼와 레이스(21, 1.49\%), 코듀로이(12, 0.85\%), 진(2, 0. $14 \%)$ 으로 나타났다.

이를 통해 알 수 있는 바, 큐비즘스타일패션에는 면, 새틴, 가죽, 실크 등 표면 요철감이 적은 플랫한 소재들이 많이 사용되었고, 특히 가죽이나 메탈릭 등의 빈도가 높게 나타난 것은 큐비즘의 기하학적. 도형적·매니쉬한 느낌을 표현하는데 용이한 까닭으 로 사료된다.

디테일이 큐비즘적 스타일을 표현하기 위해 다양 하게 사용되었는데 이를 살펴본 결과, 입체적 표현(4 $23,17.08 \%)$, 과장·확대·연장(345, 13.93\%), 왜곡(27 $6,11.14 \%)$, 해체·전치·도치(273, $11.02 \%)$, 기하학적 면 분할(188, 7.59\%), 소재 믹스매치(165, 6.66\%), 
겹침·반복(149, 6.02\%), 비대칭적 구조(146, 5.89\%), 라운드 커팅(77, 3.11\%), 드레이프(66, 2.66\%), 레이 어드( $64,2.58 \%)$, 아웃 커팅(55, 2.22\%), 기하학적 프린팅(50, 2.02\%), 구김(48, 1.94\%), 패치워크(42, $1.70 \%)$, 묶음.엮음(30, 1.21\%), 누빔(패딩)(24, 0.9 $7 \%)$, 페이크(fake)(20,0.81\%), 없음(19,0.77\%), 추 상적 프린팅(17, 0.69\%) 순으로 나타났다. 즉, 큐비 즘스타일패션을 표현하는데 있어 '입체적 표현', '과 장·확대·연장', '왜곡', '해체·전치·도치’ 등의 디테일 표현방법이 주로 사용된 것으로 분석되었다.

마지막으로 큐비즘스타일패션에 사용된 트리밍의 종류를 분석한 결과, 없음 $(595,63.16 \%)$ 이 과반 이 상으로 가장 높게 나타났으며, 다음으로 벨트(82, 8. $70 \%)$, 기타 구조물, 주머니(59, 6.26\%) 순으로 분 석되었다. 이 결과, 큐비즘스타일패션은 부가적인 트리밍 장식보다 실루엣이나 전체적인 디테일 변화 를 통해 표현하고 있음을 알 수 있었다.

\section{3. 현대 패션에 나타난 큐비즘스타일패션 연구}

앞서 F.G.R.을 통해 큐비즘스타일패션의 조형적 디 자인 요소를 종합하여 살펴본 결과, 큐비즘스타일패 션의 특성은 Figure 1과 같이 추출되었다. 큐비즘스 타일패션을 표현하는데 있어 디테일 표현방법이 가 장 두드러지게 나타나 이를 바탕으로 큐비즘스타일 패션을 도출하였다.

선행연구와 디테일의 표현방법을 분석한 결과 큐비 즘스타일패션은 다음의 세 가지로 정의해 볼 수 있다.

1) 전위적인 구성 방법

먼저 큐비즘스타일패션은 “전위적인 구성 방법”의 성향을 띄는데, 이러한 특성은 '중첩’, '해체’등의 표 현기법을 통해 보인다. ‘중첩’이란 디테일 또는 색상 을 거듭하여 겹쳐 나타내는 방법으로 반복·방사·그

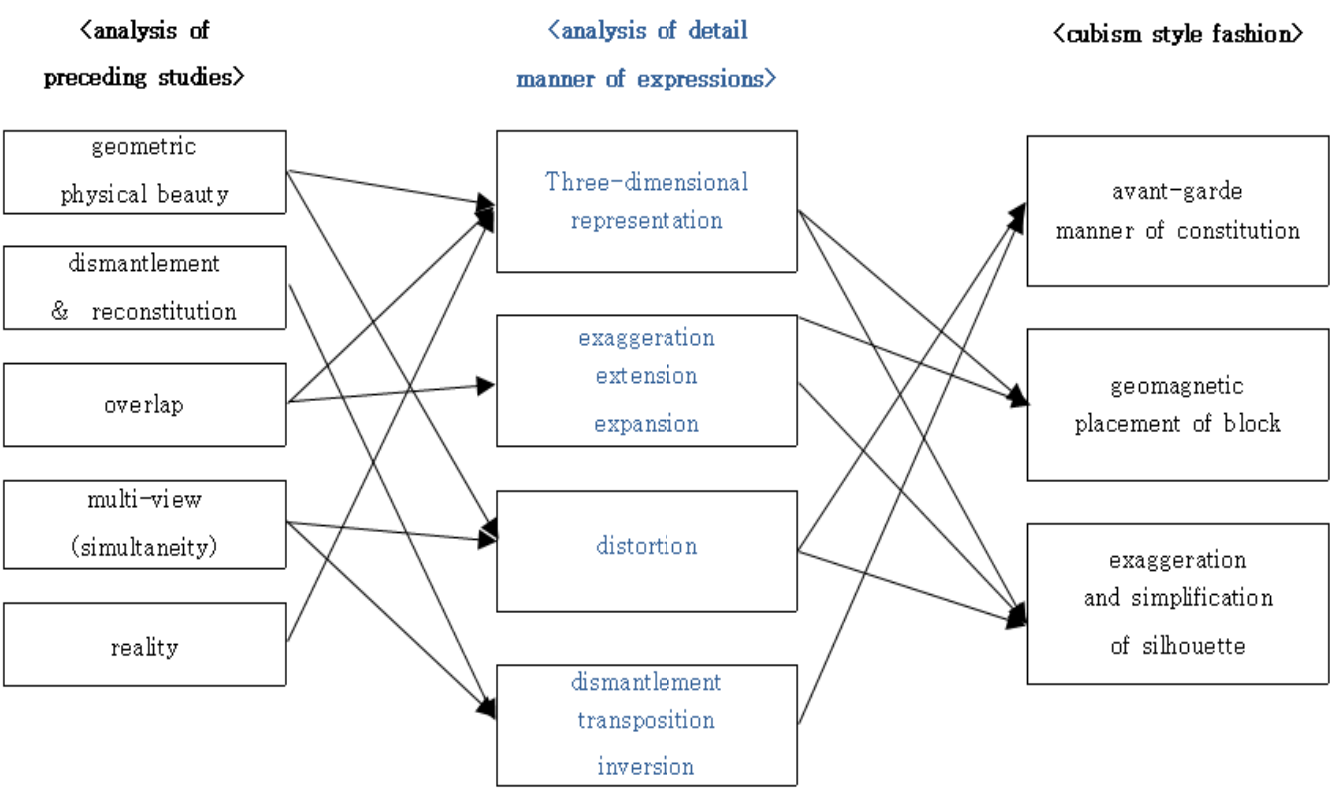

Figure 1. Cubism Fashion's Characteristics Based on Detail Manner of Expressions 
라데이션 등의 방법을 통해 연속적 혹은 규칙적인 배열을 보여주는 경우를 말한다. '해체'란 원래 있어 야 하는 자리에 없게 하여 흩어지게 하거나 분해하 는 것을 의미하는 것으로, 전치·도치와 같이 원래 위치해야 하는 곳에 위치하지 않고 위치를 바꿈으로 써 기대와 예측을 바꾸는 것을 말한다. 본 연구의 대상인 큐비즘스타일패션의 경우, '중첩'을 사용한 디테일의 표현은 색상의 반복, 트리밍의 반복, 디테 일의 반복 등을 통해 표현되고 있었다.

이를 좀 더 자세히 살펴보면 먼저, 중첩 기법 중 에서도 색상을 반복적으로 사용하여 나타낸 것으로 인도의 디자이너 매니쉬 아로라(Manish Arora)의 2010년 F/W 작품 Figure 2를 들 수 있다. Figure 2 는 블루, 오렌지, 레드 등 비비드한 색상 사이에 블 랙과 화이트를 매치하여 나머지 색들을 돋보이게 하 는 세퍼레이션 배색 기법을 반복적으로 사용한 것으 로, 특히 엉덩이 부분에 사선의 형태로 반복 배치하 는 동시에 입체감을 주어 밋밋할 수 있는 색채 중첩 기법에 리듬감을 더하였다. 조쉬 구트(Josh goot)는 2010년 S/S 컬렉션에서 Figure 3의 작품을 통해 기 하학적 패턴 배치에 모노톤의 그라데이션 효과를 사 용한 색상 배치를 한 바 있다. 그라데이션 색상의 반복을 기하학적 패턴 안에서 표현함으로써 큐비즘 적 스타일을 잘 나타내고 있다.

다음으로 트리밍의 반복을 통해 표현한 중첩 기법 을 사용한 예로, 빅터 앤 롤프(Viktor \& Rolf)의 2010년 S/S 컬렉션에서는 Figure 4와 같이 색색깔 의 쉬폰(chiffon)과 튤(tulle)을 사용하여 옷 자체의 실루엣이 주는 단조로움을 깨고 자잘한 프릴을 여러 겹으로 겹쳐 3 차원적인 형태로 나타내어 입체감을 더했다. 빅터 앤 롤프는 2011년 F/W 컬렉션 Figure 5 에서 빳빳한 소재를 사용하여 플리츠를 과장하고 반복적으로 덧붙임으로써 실루엣의 과장 및 확대까 지 보여주었다. 또한 슬리브와 어깨의 연결 부위에 반복적인 주름을 직각으로 세워 어깨를 강조하고 스 커트는 라운드 컷팅 된 조각을 스파이럴 형태로 반 복 배치함으로써 각진 상의와 부드러운 하의 간의 상반된 느낌을 대치시켜 표현하였다.

디테일의 반복을 통해 표현된 중첩의 예로는, 빅 터 앤 롤프의 2011년 S/S 컬렉션을 들 수 있다. Figure 6은 슬리브와 커프스를 과장하고 반복시킴으 로써 독특한 조형적 표현을 보여준 원피스이다. 꼼
데 가르송(Comme des Garcons)은 Figure 7에서 기존 의복이 갖고 있는 내부의 디테일 선을 모두 생 략하고 최소한의 절개를 통해 심플한 실루엣을 기하 학적 형태로 표현한 후, 오브제로 사용한 꽃을 여러 개 중첩시킴으로써 독창적이며 입체적인 느낌을 강 조하였다.

다음으로 '해체’ 기법을 통해 표현된 큐비즘스타일 패션을 살펴보면, 먼저 분해 및 재조립을 통한 해체 에서, Figure 8의 꼼 데 가르송은 2011년 S/S 컬렉 션에서 외투의 슬리브가 있을 자리에 또 다른 형태의 코트를 비대칭적으로 배치하여 기이한 실루엣을 만들 어냄으로써 의복의 구조를 완전히 왜곡시켜 새로운 형태로 재탄생시켰다. 2010년 S/S 컬렉션 Figure 9 에서는 어깨 부분의 볼록한 부분을 가슴 쪽으로 전치 시킴으로써 있어야 할 자리가 아닌 새로운 곳에 특정 형태를 두어 구조적인 형태의 변형을 꾀했다.

다음으로 착장 방법의 무시를 통한 해체의 예를 살펴보면, Figure 10은 꼼 데 가르송의 2011년 S/S 컬렉션으로 재킷의 한쪽 혹은 뒤쪽에 또 다른 재킷 을 덧붙임으로써 입는 재킷이 아닌 걸쳐진 형태의 재킷을 통해 착장 방법에 의한 해체를 보여주고 있 다. 다음으로 Figure 11은 서로 다른 두 가지의 외 투를 연결하여 원피스를 입은 후 상의에 착장하지 않고 목에 두름으로써 기존 의복의 착장 방법을 무 시하고 새로운 형태로 표현하였다.

마지막으로 다시점 표현에 의한 해체 표현에 관해 살펴보면, 큐비즘 회화에서의 동시성과 관련성이 있 다. 큐비즘 패션에서의 동시성이 가지는 의미는 다 시점에서 본 형태들을 동시에 패션에 표현되어 나타 난 것이라 할 수 있겠다. 즉 아이템의 디테일을 해 체해 정형화된 시각에서 벗어나 다양한 시점을 지닌 과장된 형태로 왜곡되어 나타난다. 이는 일반적인 옷의 형태와 착장 방법을 정형화된 실루엣들 사이에 비정형화된 사고의 차이를 통해 본질을 부각하는 시 각적 효과다. 이러한 동시성은 정형화된 패션의 스 타일이 아니라 다양한 시점의 변화를 줌으로써 시선 을 확장하며, 이러한 시각의 확장은 양적인 미적확 장 뿐만 아니라 의외성을 갖는 유희적 수단으로서 활용된다. 그 실례로 로미오 피레(Romeo Pires)의 2010년 S/S 컬렉션 작품을 들 수 있다. 측면에 위 치해야 하는 정형화된 셔츠의 소매 위치를 Figure 12 처럼 앞 중심 쪽으로 구성하여 다양한 시점에서 
본 패션의 형태를 표현함으로써 패션의 표현 영역을 확장시켰다. 또한 꼼 데 가르송은 Figure 13에서와 같이 재킷을 스커트로 사용하여 햄 라인에 라펠과

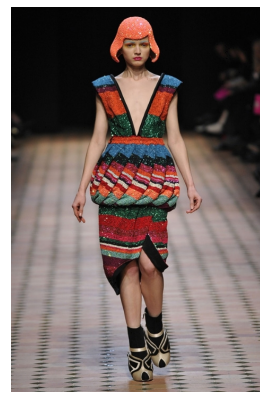

Figure 2.

Manish Arora 2010 F/W RTW

- unw.firstviewkorea.com

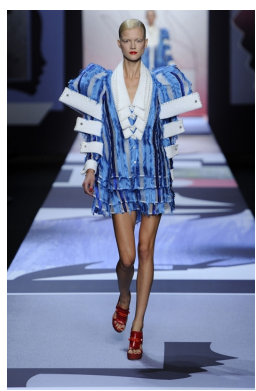

Figure 6 VIKTOR \& ROLF 2011 S/S RTW

- unw.firstviewkorea.com

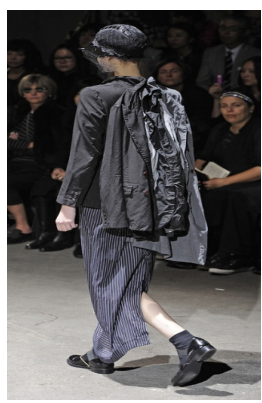

Figure 10.

Comme des Garcons 2011 S/S RTW

- unw.firstviewkorea.com

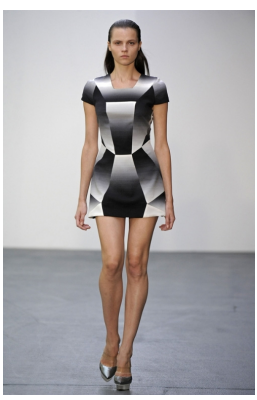

Figure 3.

Josh Goot 2010 S/S RTW

- unw.firstviewkorea.com

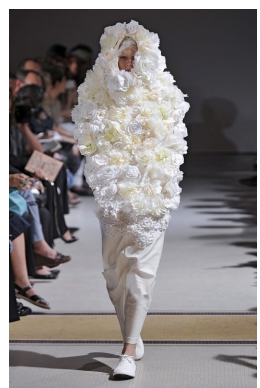

Figure 7.

Comme des Garcons 2012 S/S RTW

- wnw.firstviewkorea.com

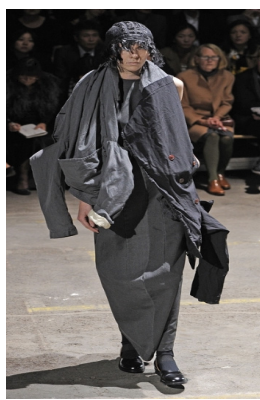

Figure 11.

Comme des Garcons 2011 S/S RTW

- www.firstviewkorea.com

슬리브가 위치하도록 배치함으로써 다각도 시점에서 본 새로운 형태를 제안하여 의복구성의 본질적 질서 를 부정한 유니크한 원피스를 선보였다.

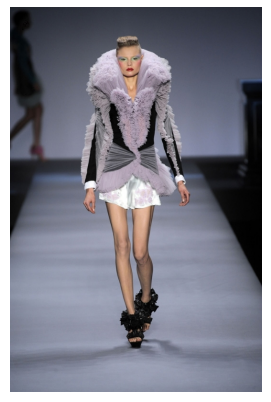

Figure 4. VIKTOR \& ROLF 2010 S/S RTW

- wnw.firstviewkorea.com

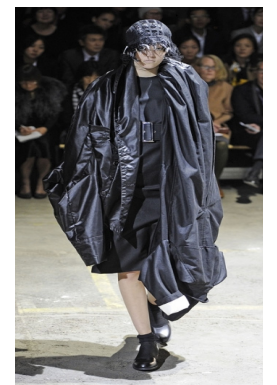

Figure 8.

Comme des Garcons 2011 S/S RTW

- wuw.firstviewkorea.com

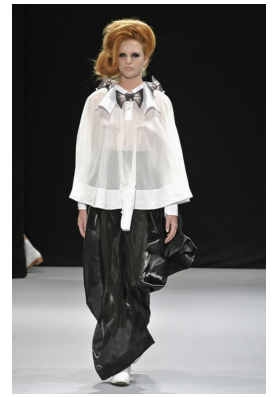

Figure 12.

Romeo Pires 2010 S/S RTW

- www.firstviewkorea.com

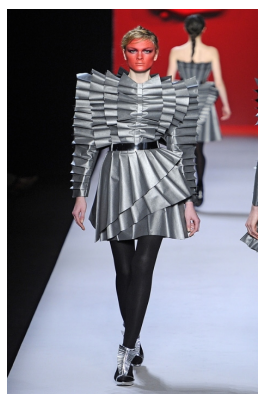

Figure 5

VIKTOR \& ROLF 2006 F/W RTW

- uww.firstviewkorea.com

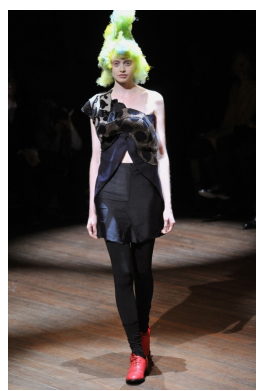

Figure 9

Comme des Garcons 2010 S/S RTW

- unw.firstviewkorea.com

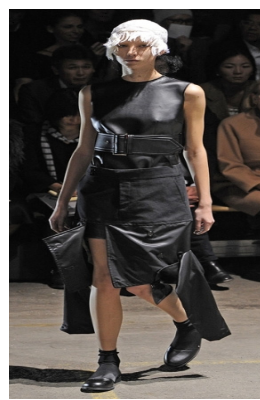

Figure 13.

Comme des Garcons 2011 S/S RTW

- unw.firstviewkorea.com 
2) 지오메틱한 블록 배치

다음으로 현대 패션에 나타난 큐비즘스타일패션 에서는 컷팅·분해, 프린트, 패치워크 등의 기법을 통 해 기하학적인 면 분할이 많이 나타났으며 다양한 형태의 독특한 오브제를 통한 입체적 표현이 자주 보였는데, 이러한 특성을 ‘지오메틱한 블록 배치’로 정리하였다.

먼저 '기하학적 면 분할'을 통한 표현을 살펴보 면, 재단 등에 의해 나누어진 패턴·패널을 기하학적 인 형태로 다채롭게 분할함으로써 다양한 모습으로 패션에 적용하였다. 특히 컷팅, 프린트, 패치워크 등 의 기법을 사용하였는데, 먼저 컷팅·분해를 통한 패 널 분리의 예로는 페드로 로렌코(Pedro Lourenco) 의 2013년 S/S 컬렉션의 작품 Figure 14로 기하학 적 커팅을 사용하여 패널을 분리하여 표현함으로써 고스적인 분위기를 큐비즘적으로 해석·표현하였다. 꼼 데 가르송은 Figure 15에서 기하학적 면 분할로 나누어진 각각의 패널에 이질적 소재를 믹스매치하 고, 각각의 패널에 라운드 컷팅함으로써 이질적 소 재의 대비를 극대화시켰다. 스테피 크리스티안 (Steffie Christiaens)은 Figure 16에서 기하학적인 컷팅으로 패널을 분리시키고 부분적으로 천을 덧붙 여 입체적으로 표현하였다.

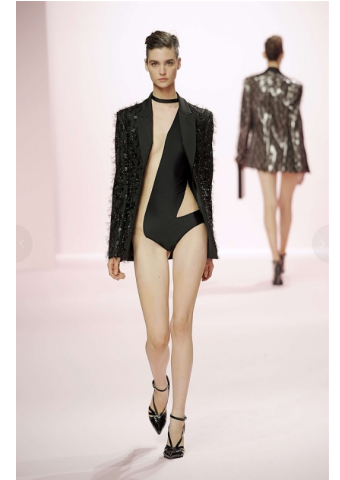

Figure 14.

Pedro Lourenco 2013 S/S RTW

- www.firstviewkorea.com

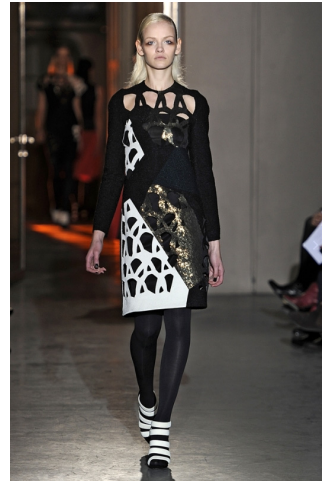

Figure 15

Comme des Garcons 2012 F/W RTW

- www.firstviewkorea.com

다음으로 프린트를 이용하여 지오메틱한 블록 배 치를 표현한 작품을 살펴보면, Figure 17의 이세이 미야케 작품에서는 지그재그와 하운드 투스 패턴을 상·하의에 각각 배치하여 써피스 프린트하여 표현하 였으며, 입체적인 칼라가 드레이프로 연출되는 베스 트를 착장함으로써 큐비즘적 느낌을 강조하였다. 한 편, Figure 18에서 보여지듯이 알렉산더 맥퀸은 파 충류나 바다생물이 떠올려지는 추상적인 문양을 대 칭으로 배치하여 디지털 프린팅 하였는데, 이는 에 어리한 소재와 함께 조화롭게 연출되었다.

패치워크로 표현된 면 배치의 예로, 매니쉬 아로 라의 2010년 F/W 컬렉션에서 선보인 작품 Figure 19 는 다양한 컬러로 면 분할된 원피스 위에 입체적 인 형태의 패치워크 볼레로를 더해 큐비즘적 패션을 완성하였다.

다음으로 '오브제에 의한 입체적 표현'을 통한 큐 비즘스타일패션을 살펴보면, Figure 20에서 꼼 데 가르송은 외투를 페티코트 형태의 오브제로 사용하 면서 페티코트 골격 형태를 그대로 겉으로 드러내고 슬리브 등의 디테일을 생략함으로써 충격적인 실루 엣을 만들어냈다. Figure 21은 아르주 캐프롤(Arzu Kaprol)의 $2011 \mathrm{~F} / \mathrm{W}$ 컬렉션 작품으로, 입체적인 원 통형의 상의에 스터드 등의 메탈 소재 트리밍을 빽 빽하게 달아 오브제를 사용한 입체적인 표현을 잘 나타낸 작품이다.

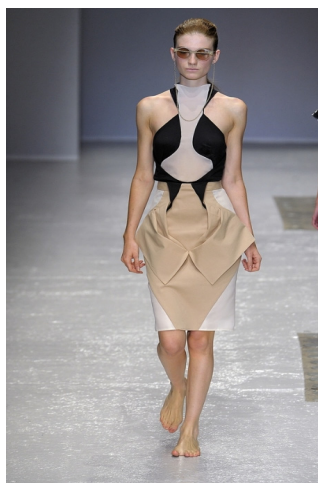

Figure 16.

Steffi Chrishan 2013 S/S RTW

- www.firstviewkorea.com

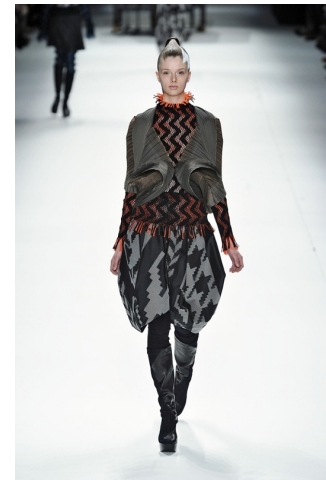

Figure 17. Issey Miyake 2011 F/W RTW

- wnw.firstviewkorea.com 


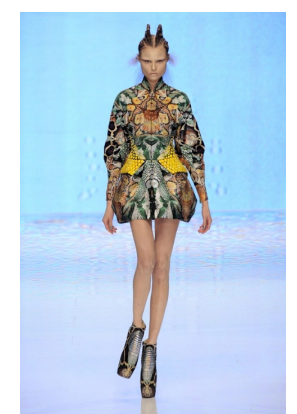

Figure 18.

Alexander Mcqueen 2010 S/S RTW

- www.firstviewkorea.com

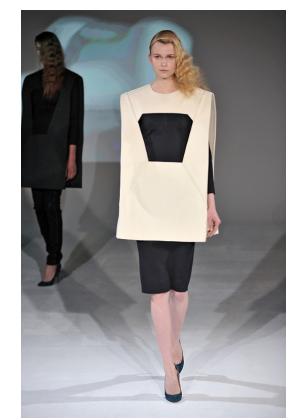

Figure 22. Hussein Chalayan 2012 F/W RTW

- unw.firstviewkorea.com

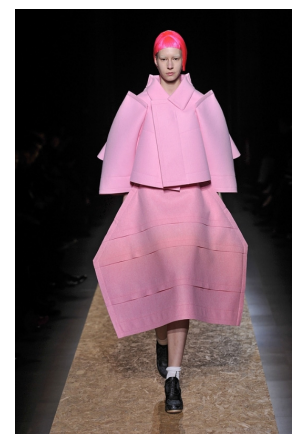

Figure 26.

Comme des Garcons 2012 F/W RTW

- www.firstviewkorea.com

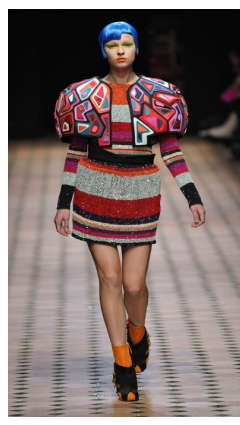

Figure 19.

Manish Arora 2010 F/W RTW

- www.firstviewkorea.com

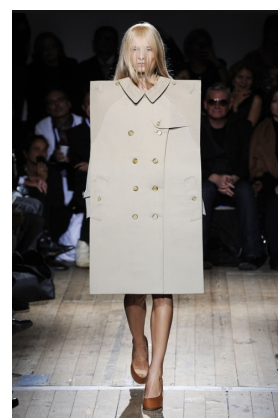

Figure 23

Maison Martin Margiela 2011 S/S RTW

- www.firstviewkorea.com

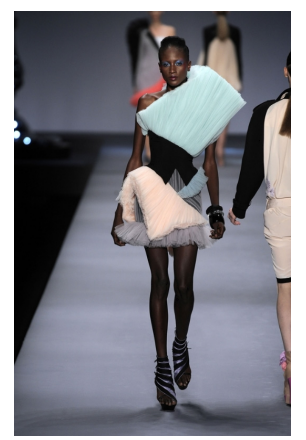

Figure 27.

VIKTOR \& ROLF 2010 S/S RTW

- unw.firstviewkorea.com

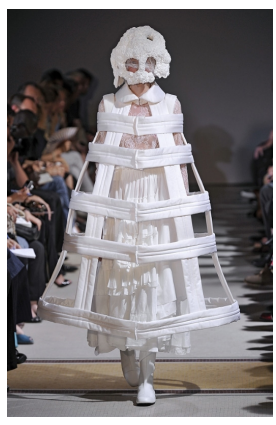

Figure 20.

Comme des Garcons 2012 S/S RTW

- www.firstviewkorea.com

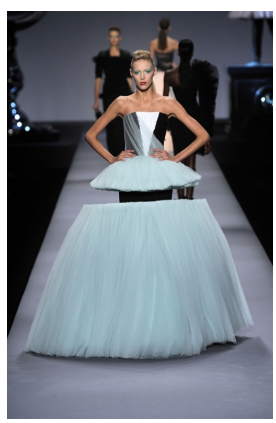

Figure 24. VIKTOR \& ROLF 2010 S/S RTW

- www.firstviewkorea.com

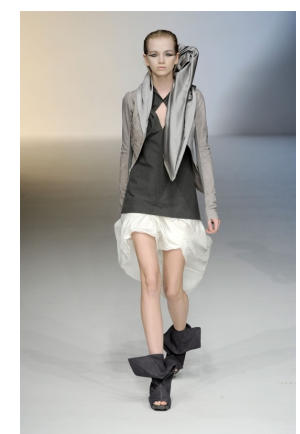

Figure 28.

Rick Owens 2010 S/S RTW

- www.firstviewkorea.com

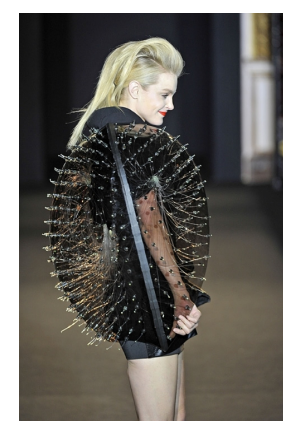

Figure 21.

Arzew Kefrol 2011 F/W RTW

- unw.firstviewkorea.com

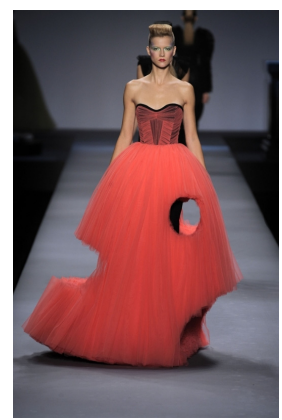

Figure 25.

VIKTOR \& ROLF

2010 S/S RTW

- unw.firstviewkorea.com

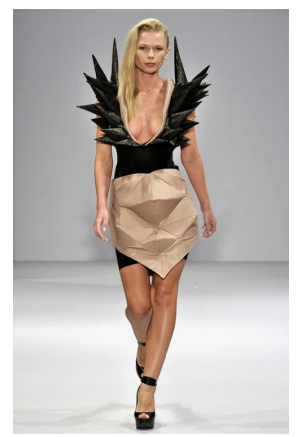

Figure 29.

Blythe Damis Emi 2010 S/S RTW

- unw.firstviewkorea.com 
3) 실루엣의 왜곡 및 단순화

마지막으로 현대 패션에 나타난 큐비즘스타일패션 은 여성의 인체가 갖고 있는 고유의 곡선미를 부정 하고 평면적 혹은 3 차원적으로 조작·왜곡하여 실루 엣을 생략·단순화 시키거나 기존의 디테일을 확대. 연장함으로써 '실루엣의 왜곡 및 단순화'를 통해 표 현되었다. '왜곡'이란, 예술에서 원형과 그 표상 간 의 의도적이거나 비의도적으로 나타나는 차이를 가 리키는 용어로써(“Glossary of world art,” 2014), 미술용어사전에 나타난 왜곡에 대한 용어 정의는 다 양하지만 패션에 있어서 왜곡의 개념은 인체의 이상 적 형태를 이탈해 만들어진 것, 즉 강조와 과장, 확 대 등의 방법으로 인체의 자연적 비례를 무시한 복 식으로 정의할 수 있다(Kim, 2009). '단순화’는 복잡 하지 않고 간단하며 단조롭게 만들어지는 형태로 인 체의 실루엣이나 의복의 구조를 단순화시켜 왜곡되 어 표현한 것을 말한다. 이러한 특성은 평면적 혹은 3 차원적으로 왜곡시키거나 실루엣의 단순화 혹은 디 테일-트리밍의 확대 및 연장에 의해 표현되는 것으 로 나타났다.

먼저 '평면적 왜곡'을 표현한 예를 살펴보면, 후 세인 샬라얀(Hussein Chalayan)은 Figure 22에서 여성 인체 곡선미를 철저히 부정하고 직사각형의 플 랫한 형태의 실루엣으로 표현하였으며, 메종 마틴 마르지엘라(Maison Martin Margiela)는 Figure 23에 서 트렌치 코트가 그려진 빳빳한 종이를 어깨에 걸 친 듯한 평면적인 직사각형 실루엣을 표현하였다.

다음으로 '3차원적 조작' 기법의 예로, Figure 24 에서 빅터 앤 롤프는 3차원적으로 면을 마치 전기톱 으로 잘라낸 듯한 독창적인 컷팅감이 돋보이는 드레 스를 선보였다. Figure 25는 튤 소재로 만든 드레스 의 중간을 뻥 뜷어서 안이 보이게 하는 드레스로, 소재의 특성을 적극 이용하여 3차원적인 왜곡·조작 을 진행하였다.

다음으로 '실루엣의 생략'을 통한 큐비즘스타일패 션의 표현 사례를 살펴보면, 2012년 F/W 꼼 데 가 르송의 '미래는 평면적이다.'라는 컨셉을 가진 컬렉 션을 볼 수 있다. Figure 26에서는 실루엣을 단순화 시켜 생략시킴과 동시에 과장되게 표현한 평면적 디
자인을 전개하였으며 단순화한 실루엣의 오버사이즈 의상으로 패션에 대한 고정관념을 무너뜨렸다. 뿐만 아니라 단추와 지퍼 없이 단순한 형태들로 만들어 새로운 의복의 개념을 정립하였으며, 인체의 실루엣 을 생각하지 않고 단순화시킨 표현이 마치 종이 인 형 같은 인상을 주었다.

마지막으로 ‘디테일·트리밍을 확대하고 연장'함으 로써 큐비즘스타일패션을 표현하였는데, Figure 27 에서 빅터 앤 롤프는 얇은 소재를 여러 겹으로 겹쳐 3차원적인 도형의 형태를 어깨와 스커트에 어시매트 릭(asymmetric)하게 배치하고, 이를 사선으로 다시 잘라 마치 인체가 도형 안에 들어가 있는 느낌을 연 출하였다. Figure 28은 릭 오웬스(Rick Owens)의 작품으로 재킷의 한쪽 칼라만 지오메트릭한 도형의 형태로 확대시켜 어시매트릭하게 표현하였다. 다음 으로 브라이스 다미스 에미(Bryce Damice Aime)의 Figure 29에서는 베스트 어깨를 입체적인 실루엣으 로 확대시켜 공작새 느낌을 주었고, 스커트는 패널 을 기하학적으로 재단하여 입체적인 요철감을 표현 하였다.

\section{V. 결론 및 제언}

본 연구는 2010년-2013년 파리 컬렉션 작품 중 F.G.R. 분석을 통해 객관적인 방법으로 큐비즘과 관 련 깊은 패션스타일을 선정하고, 선정된 큐비즘스타 일패션의 조형적 디자인 요소를 분석함으로써 현대 패션에 나타난 큐비즘스타일패션의 특성을 분석하는 것을 목적으로 하였으며 연구의 결과는 다음과 같 다.

아이템 분포의 경우 ‘원피스'가 가장 많은 것으로 분석되었고, ‘H 실루엣’이 주를 이루었으며 '면' 소 재의 사용빈도가 높은 것으로 나타났다. 색상의 경 우, 주로 사용된 색상은 '레드, 옐로우, 블루 계열' 정도로 국한되었으며 '저채도와 무채색'의 빈도가 높은 것으로 분석되었다. 배색은 '솔리드'가 대부분 이었으며, 트리밍은 거의 사용하지 않는 것으로 보 였다. 디테일 표현방법의 경우, 큐비즘스타일패션은 입체적 표현, 과장·확대·연장, 왜곡, 해체·전치·도치, 
기하학적 면 분할 등을 통해 의복 디테일의 변화를 보여주는 것을 알 수 있었다. 이외에도 소재 믹스매 치, 겹침·반복, 비대칭적 구조 등의 표현 방식이 사 용된 것으로 분석되었다. 이상의 결과는 큐비즘적 성향 표현에 있어 용이하기 때문인 것으로 사료되었 다. 즉, 기하학적이고 심플하며 입체적인 디테일 표 현을 주로 하는 큐비즘적 성향을 표현하는데 이와 같은 디자인 요소의 조건이 적합한 것으로 나타났 다.

이상의 실증적 자료의 분석 결과를 통해 큐비즘스 타일패션에 나타난 여러 가지의 표현 방식들을 종합 하고 정리하여 세 가지 특성을 도출할 수 있다.

먼저, '전위적인 구성 방법'이다. 현대 패션에서 색상-트리밍·디테일의 반복적 사용을 통한 '중첩'기 법의 빈번한 활용이 큐비즘적 스타일로 연결되었으 며 의복 구성을 위한 여러 디테일 요소를 분해한 후 다시 재조립, 기존의 착장 방법에서 벗어난 착장의 형태를 보여주거나 보는 각도에 따라 다르게 보이는 여러 형태의 집약된 형태로 제시되는 다시점 표현을 통해 집대성된 ‘해체’기법의 표현이 전위적인 구성 형태로 나타나 큐비즘스타일패션을 표현하는 것으로 보여 졌다.

다음으로 '지오메틱한 블록 배치'이다. 컷팅·분해 등을 이용한 물리적 조작에 의한 패널 분리나 프린 트 혹은 패치워크 기법을 이용하여 기하학적 면 분 할을 통해 큐비즘적 느낌을 표현하였다. 뿐만 아니 라, 입체적인 오브제를 사용함으로써 큐비즘적 느낌 을 강조하였다.

마지막으로 '실루엣의 왜곡 및 단순화'이다. 인체 의 윤곽선의 미를 극대화시키기 위해 사용되는 의복 의 구성선 및 실루엣을 평면적으로 납작하게 눌러 왜곡하거나 3 차원적인 조작을 통한 왜곡, 전혀 다른 형태로 생략하여 단순화시키거나 세부 디테일 트리 밍을 확대 혹은 연장 하는 형태로 표현하는 방법을 통해 큐비즘적 스타일을 나타내고 있었다.

본 연구는 20 세기에 등장한 예술 운동 중 가장 실 험적이고 새로운 모더니즘의 시작이라 칭해지며 현 대 디자인에 큰 영향을 미친 예술양식인 큐비즘을 살펴보고 현대 패션 디자인에서 나타난 큐비즘적 디 자인 요소를 분석하여 큐비즘적 패션 스타일을 규명
하고 이를 하나의 패션 스타일로 확립하려 하였다. 나아가 패션 디자인 영역에서 큐비즘패션스타일로서 의 자리를 확립하는 가능성을 제시하는데 일조할 수 있으리라 기대한다.

본 연구에서는 현대 패션 디자인에서 나타난 큐비 즘적 요소를 분석하여 큐비즘적 패션 스타일을 규명 하는데 그쳤지만, 후속 연구에서는 큐비즘스타일을 다양하게 다루어 큐비즘 패션 디자인으로 제시하는 연구가 되길 기대한다.

\section{References}

Chae G. (2002), Modern dress aesthetics, Seoul: Gyeongchunsa.

Edward, F. F. (1985). Cubism. (I. Kim, Trans.). Seoul: mijinsa. (Original work published 1995).

Glossary of world art, 'distortion'. (2014). Retriev ed from http://terms.naver.com/entry.nhn?cid= 170\&docld=894834\&mobile\&categoryld=170

Ju, M. (1990), A study on the modern fashion u nder the influence of Fauvis (Unpublished doc toral dissertation). Chung-Ang University, Seou I, Korea.

Kang, K. (1992), A Study on the Dress Design U sing P. Picasso's cubistic Work (Unpublished master's thesis). Ewha Women University, Seo ul, Korea.

Kim, E. (2009), A Study on Modern Fashion Desi gn Utilizing Memphis Design's characteristics (Unpublished master's thesis). Hong-Ik Univer sity, Seoul, Korea.

Lee, D. (2003), The Fashion Design Applying to the Formation of Cubism Arts (Unpublished $\mathrm{m}$ aster's thesis). Keimyung University, Daegu, K orea.

Lee, E. (2002), The Formative Characteristics of the Cubism expressed in Modern Fashion (Un published doctoral dissertation). Daejeon Univ ersity, Daejeon, Korea. 
Neil, C. (2003), Cubism a\&i. (S. Cheon, Trans.). S eoul: Hangilart. (Original work published 2000).

Park, H. (2004), The phenomena of body absen $\mathrm{ce}$ and irrepresentation in the late twentieth $\mathrm{c}$ entury fashion (Unpublished doctoral dissertati on). Hong-Ik University, Seoul, Korea.

Song, A. (2009), A study on fashion design ada pting cubism aesthetics (Unpublished master's thesis). Hong-Ik University, Seoul, Korea.

Sung, P. (2011), A study on fashion design ada pting geometric form of analytic cubism aesth etics (Unpublished master's thesis). Ewha Wo mans University, Seoul, Korea.

Yoon, J. (2006), Study on expression in self-portr ait by using cubism style (Unpublished master' $s$ thesis). Kook-Min University, Seoul, Korea.

Yu \& Kim. (1993), A study on concentrated on $t$ he years between 1910s and 1920s: Effects o $n$ the modern clothes-design by the art of th e Cubism. Research Bulletin. 46(1), 193-220.

Collection 2010 S/S-2013 F/W RTW. (2013, Dec ember 1 - 2012, March 30). firstviewkorea, R etrieved from http://www.firstviewkorea.com

Received(January 10, 2014)

Revised(March 17, 2014)

Accepted(June 5, 2014) 